\title{
Incidence of Insect-Pests on Rice in Faizabad
}

\author{
Yadav Abhinandan ${ }^{1}$, P.K. Gupta ${ }^{1}$ and Kurulkar Uday ${ }^{2}$ \\ ${ }^{1}$ Department of Entomology, NDUAT, Kumarganj, Faizabad, Uttar Pradesh, India \\ ${ }^{2}$ Department of Nematology, Assam Agricultural University, Jorhat, Assam, India
}

*Corresponding author:

\begin{abstract}
A B S T R A C T
Keywords

Rice pest,

Temperature,

Humidity etc.

Article Info

Accepted:

07 May 2019

Available Online:

10 June 2019

The field experiment was conducted at main experimental station of Narendra Deva University of Agriculture and Technology, Kumarganj Faizabad (U.P.) during the season kharif, 2015 to know the occurrence and abundance of insect-pests of paddy on rice crop was monitored on rice variety Pusa Basmati. This investigation revealed that pest activity commenced from $31^{\text {th }}$ Standard meteorological week (SMW) and continued upto $49^{\text {th }}$ SMW. The peek population of rice hispa was found in the $31^{\text {st }} \mathrm{SMW}$, green leaf hopper was found in the $37^{\text {th }}$ SMW, grass hopper and yellow stem borer was found in the $39^{\text {th }}$ SMW and leaf folder was found in the $41^{\text {st }}$ SMW. Population of yellow stem borer (YSB) was positively correlated with maximum temperature. The population of rice hispa had non-significant and positive correlation with rainfall and maximum temperature. The population of green leaf hopper showed positive and significant correlation with minimum and maximum temperature, relative humidity and rainfall. The population of rice leaf folder showed negative correlations with minimum and maximum temperature and relative humidity.
\end{abstract}

\section{Introduction}

Rice is the main staple food not only for India but also for other countries. It is mainly grown on the low line deltas of the Brahmaputra and Barak valley which consider as rice bowl of India. Apart from that Uttar Pradesh also contributes 56.57 lakh ha area with a productivity of 2.12 per ha and 119.92 lakh ton production of rice (Anonymous, 2012). The production and productivity of rice is governed by biotic and abiotic factors. The abiotic factors like temperature, rainfall,
Sunshine, relative humidity etc. play vital role in growth and development of rice. The biotic factors such as disease and pests affect the rice at different growth stages. Among them pests, insect showed more incidences on rice at different growth stages. Among insect pests, yellow stem borer Sciropophaga incertulas, Leaf folder Cnapholocris medinalis, Rice hispa Dicladispa armigera, Green leaf hopper Nephotettix spp.and Grass hopper Hieroglyphus banian etc. were attacks on rice at different growth stages and caused huge losses in rice (Anonymous, 2003). The 
abiotic factors also determine the dynamic nature of insect-pests (Kennedy and Storer, 2000) and show their influence on the incidence at different growth stages of rice. The knowledge of insect-pest populations play an important role in the formulating of protection strategies (Milford and Dugdale, 1990) and but also helps in the forecasting of the population on daily, seasonally or as long term in concern with the climate change (Denholm et al., 2000). Keeping in this view a study was carried out to know the occurrence of insect-pests of rice under Uttar Pradesh condition.

\section{Materials and Methods}

The field experiment was carried out to know the occurrence of insect-pests of rice at Crop Research Station (crop research station), Masodha unit $1^{\text {st }}$ of Narendra Deva University of Agriculture and Technology, Kumarganj, Faizabad-224 229 (U.P.) which fall under the subtropical region in indo-gangatic plains and lies at $26.4{ }^{0}$ North latitude and $82.12{ }^{0} \mathrm{E}$ east longitude at an altitude of 113 meter from mean sea level. The fields were having sandy loam soil condition. Total experimental plot size measured $1500 \mathrm{~m}^{2}$. The seedlings were transplanted in the experimental plot with spacing $20 \mathrm{~cm}$ between plant to plant and 15 $\mathrm{cm}$ row to row. 25 days old seedlings of Pusa Basmati-1 rice variety were transplanted 25 July 2015 from the nursery sown 24 days ago, in experimental year. The normal cultural practices were performed throughout the growing season of the crop. Data were recorded after 15 days of transplanting and subsequent after 7 days of intervals upto harvest of the crop by using net and hand collection method.

\section{Results and Discussion}

The incidence of rice insect pests like yellow stem borer Sciropophaga incertulas, Leaf folder Cnapholocris medinalis, Rice hispa Dicladispa armigera, Green leaf hopper Nephotettix spp. and Grass hopper Hieroglyphus banian were observed at different growth stages of rice. In the present investigation it observed that the population of above insect-pests was fluctuated at different temperature, rainfall, Sunshine and relative humidity. The incidence of rice hispa maximum at tillering stage of rice and it caused yellowing and bronzing of leaves. The peek population of rice hispa (2.6 Rice Hispa /five sweeps) noticed at $31^{\text {st }}$ standard week with temperature ranging from 26 to $35.50^{\circ} \mathrm{C}$, $77.80 \%$ relative humidity and $2.0 \mathrm{~mm}$ average weekly rainfall. Further the incidence of rice hispa was declined from 1.70 Rice Hispa /five sweeps at 32 standard week, 1.03 Rice Hispa /five sweeps at 33 standard week, 0.74 Rice Hispa /five sweeps at 34 standard week. However, no incidence of rice hispa was observed from 35 to 46 standard weeks expect at 38 standard weeks (0.19 Rice Hispa /five sweeps) which recorded least incidence. Similar results were also observed by Kumar (2002) who recorded the incidence of ricehispa in irrigated rice at Tungabhadra Project Area of Karnataka. In the present investigation the Green leaf hopper were occurred at dough stage of rice. However the incidence of green leaf hopper were increasing from 31 standard week (1.40 green leaf hopper /five sweeps) to 37 standard week and recorded peek population (3.93 green leaf hopper /five sweeps) where temperature ranging $25.70-32.60^{\circ} \mathrm{C}$ and $73.10 \%$ relative humidity recorded. Future, in the present investigation the incidence of green leaf hopper were decreasing from 38 standard week (2.46 green leaf hopper /five sweeps) to 46 standard week (0.76 green leaf hopper /five sweeps) and recorded to be the least population. Soekhardjan et al., (1974) who observed that similar type of observations on the rice and recorded that leafhopper showed more incidences at the time of maturity of 
crop. Likewise, Kumar (2002) and Rajendraprasad et al., (2011) were reported the population of green leaf hopper at the time of panicle initiation of rice. The maximum population of grass hopper was recorded at tillering stage of crop with 4.30 per five sweeps at 39 standard weeks. The population was started from $31^{\text {st }}$ standard week to the extent of 1.63 grass hopper per five sweeps. The incidence of grass hopper population of was increased simultaneously 2.09, 2.36, 2.60, 3.13, 3.8 and 3.60 grass hopper per five sweeps respectively from $2^{\text {nd }}$ week of August to $2^{\text {nd }}$ week of September. The population reached to the peak (4.30 per five sweeps) $39^{\text {th }}$ standard week during this period the temperature ranging from $22.30^{\circ} \mathrm{C}-30.70^{\circ} \mathrm{C}$, $60.0 \%$ relative humidity and $15.20 \mathrm{~mm}$ an average weekly rain fall. The population of grass hopper at was build up from 3.13, 3.80, $3.61,4.06,4.30,3.53,3.73,3.06$, and 3.43 grass hopper per five sweeps were recorded from at 35 to 43 standard week and found to be the best period for the maximum incidence of grass hopper. Khan (2013) also found that the highest percent of relative abundance of grasshopper was most prevalent in the rice field. Thus confirm the result of the present investigation. The population of leaf Folder reached to the peak (22.53 per five sweeps) in $41^{\text {st }}$ standard week during this period the temperature ranging from $20.30^{\circ} \mathrm{C}-31.50^{\circ} \mathrm{C}$ with $56.90 \%$ relative humidity. However, the population was decreased $42^{\text {nd }}$ standard week onward up to maturity of crop. The leaf folder population of was increased simultaneously $10.13,12.73,18.10,20.72,22.53,21.30$ and 19.30 leaf Folder per five sweeps respectively from 37-43 standard week and found to be the best period for the maximum incidence of leaf folder. The present findings are in confirmation with the report made by Sachan (1992) and Faleiro et al., (2001). The maximum population of yellow stem borer was recorded (5.16 per five sweeps) at $39^{\text {th }}$ standard weeks during this period the temperature ranging from $22.30^{\circ} \mathrm{C}$ to $30.70^{\circ} \mathrm{C}$ and $58.60 \%$ relative humidity were recorded. The population of yellow stem borer was started from $31^{\text {st }}$ standard week to extent of 0.30 per five sweeps. The population of yellow stem borer was increased simultaneously $0.36,1.20,1.71,2.12,2.80$, $3.73,2.86$ and 5.16 yellow stem borer per five sweeps respectively from 32 to 39 standard week and found to be the best period for the incidence of yellow stem borer. The results are in conformity with earlier findings of Rustamani et al., (1985), Sharma et al., (1995), Sontakke et al., (1987), Kumar (2002) and Rajendraprasad et al., (2011) (Fig. 1).

\section{Correlation}

Population of yellow stem borer (YSB) was non-significantly negatively correlated with minimum temperature (-0.0349) and rainfall $(-0.1598)$ while it had negative and significant association with relative humidity $(-0.5395)$. However the population of rice yellow stem borer was non-significant and found to be positive correlated with maximum temperature (0.1769). The correlation studies on rice hispa $(\mathrm{RH})$ revealed that the population and damage had significant correlation with relative humidity (0.6510) and minimum temperature (0.4631). Where as rice hispa had non-significant and positive correlation with rainfall (0.2637) and maximum temperature (0.1711). The population of green leaf hopper (GLH) showed positive and significant correlation with minimum temperature (0.7708), maximum temperature (0.6419), relative humidity (0.5195) and rainfall (0.4419). However no negative correlation of green leaf hopper was recorded with any abiotic factor. The population of grass hopper $(\mathrm{GH})$ was non-significantly and negatively correlated with minimum temperature and rainfall (0.1085 and -0.2575 ) (Fig. 2). 
Fig.1 Occurrence of rice insect pests from $31^{\text {st }}$ standard weeks to $46^{\text {th }}$ standard weeks during 2015. (YSB=Yellow stem borer, RH=Rice Hispa, $\mathrm{GLH}=\mathrm{Green}$ leaf hopper, $\mathrm{GH}=\mathrm{Grass}$ hopper, $\mathrm{LF}=$ Leaf folder)

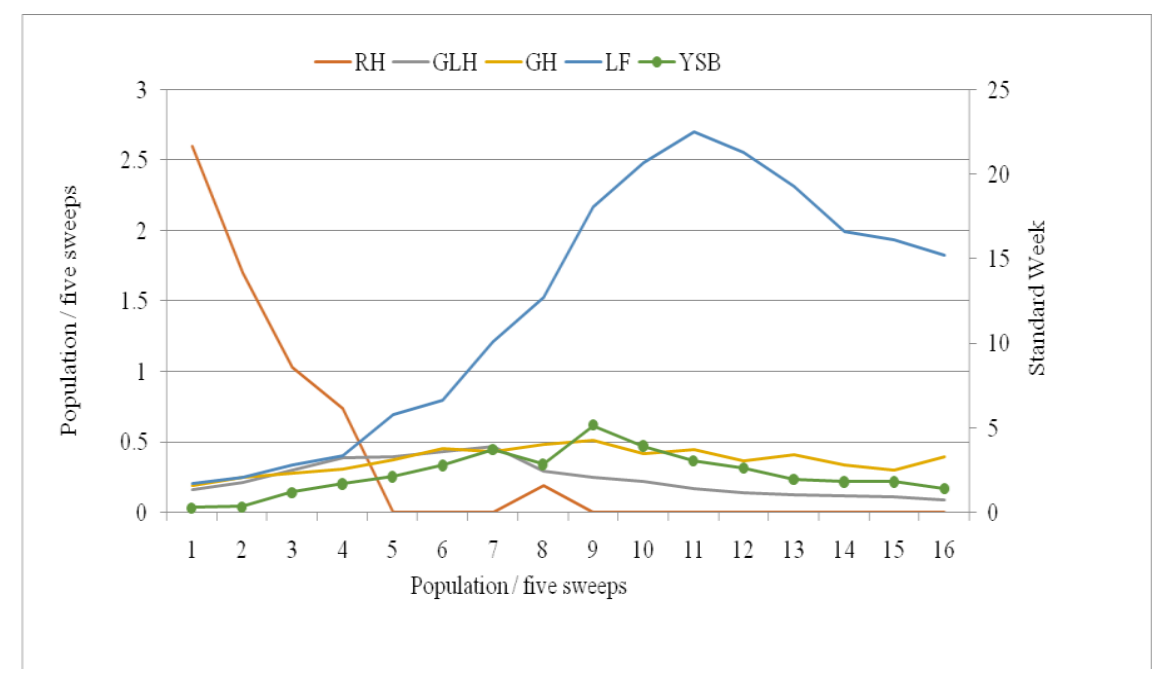

Fig.2 Correlation of major insect pests with abiotic factors kharif 2015

*= significant at 5\% level (YSB=Yellow stem borer, RH=Rice Hispa, GLH=Green leaf hopper,

$\mathrm{GH}=$ Grass hopper, $\mathrm{LF}=$ Leaf folder)

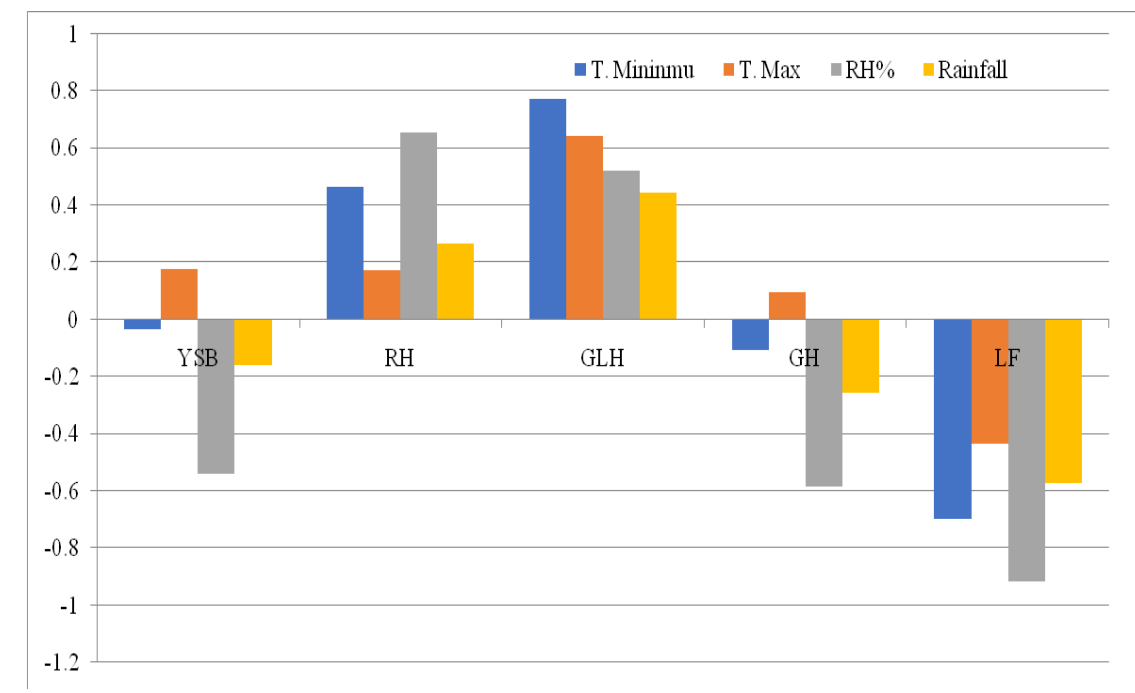

The population of grass hopper was significantly negatively correlated with relative humidity $(-0.5860)$ and nonsignificant positive correlation was found with maximum temperature (0.0934). Results of correlation studies effect of abiotic factor on population of leaf folder rice revealed that there were negative correlations with minimum and maximum temperature, relative humidity and rainfall -0.6992, -0.4347, 0.9168 and -0.57138 respectively.

\section{References}

Anonymous, 2012. Annual Progress report, Directorate of Agriculture statistics, Uttar Pradesh.

Anonymous, 2003. Progress Report 2002, 
Vol. 2 (Entomology and Pathology). All India Coordinated Rice Improvement Programme, Directorate of Rice Research, Rajendra Nagar, Hyderabad, A.P, India pp. 36-39.

Denholm, I., Chapman, J. W., Denholm, C., Harrington, R and Woiwod, I. P. Insect population dynamics. Institute of Arable Crops. Research Report. 2000-2001, Pp. 24-27.

Faleiro, J.R. Patil, K.D. and Viraktamath, B.C. 2001. Incidence of leaf hopper, Cnaphalecrocis medinalis and gall midge Orselia oryza on medium duration rice varieties. Indian Journal of Entomology, 63(2): 201-203.

Kennedy, G.G. and Storer, N.P. 2000. Life systems of polyphagous arthropod pests in temporally unstable cropping systems. Annual Review of Entomology. 45: 467-493.

Khan, M.M.H. 2013. Abundance and diversity of insect pests and natural enemies in coastal rice habitat. Bangladesh Journal of Entomology, 23(1): 89-104.

Kumar, V. 2002. Status of paddy insect pests and their natural enemies in Tungabhadra project area. M. Sc. (Agri.) Thesis, Univ. Agric. Sci., Dharwad (India). pp. 63-114.

Milford, J. R and Dugdale G.1990. Monitoring of rainfall in relation to the control of migrant pests, philosophical Transactions of the Royal Society of London - Series B: Biological Sciences. 328: 689-704.
Rajendra Prasad, B.S., Prabhu, S. T. and Balikai, R. A. 2011. Status of insectpests and their natural enemies on rice under rainfed eco-systems. Indian Journal of Agricultural Statistic Science. 7 (2): 373-382.

Rustamni, M. A., Khan, N. M., Talpur, M. A. and Baloch, H. B. 1995. Effect of transplanting dates on the incidence of stem borers infestation in rice. Pakistan Journal of Zoology. 27(4): 341-343.

Sachan, S. K. 1992. Rice leaf folder (LF) out break in Valleys of Uttar Pradesh (U.P.), India. International Rice Research Newsletter. 17(6): 256-260.

Sharma, D. R., Gill, P. S. and Dhaliwal, G. S. 1995. Impact of agronomic practices on the incidence of rice stem borer Scirpophaga incertulus (Walker). Indian ornal of Ecology. 22(2): 101108.

Soekhardjan, M. D., Socharna, D. and Leuwangh, J. 1974. Stem borer and gall midge infestation at different stages of the rice plant under field condition. The Netherlands Research Reports 1968-1974. Ministry of Agriculture Cooperation, Indonesia. Section 11: 126-130.

Sontakke, O. K., Panda, S. K. and Rath, L. K. 1987. Effect of dates of planting, varietal resistance and chemical control on rice stem borer incidence in western Orrisa. Indian Journal of. Entomology. 59(4): 423-429.

\section{How to cite this article:}

Yadav Abhinandan, P.K. Gupta and Kurulkar Uday. 2019. Incidence of Insect-Pests on Rice in Faizabad. Int.J.Curr.Microbiol.App.Sci. 8(06): 551-555. doi: https://doi.org/10.20546/ijcmas.2019.806.064 